\title{
Perceptions towards Codes of Behaviour: A Study of CAOs, CFOs and Other Employees in Bahrain
}

\author{
Amal Abdel Wakil \\ Department of Accounting, College of Business Administration \\ University of Bahrain, P.O. Box 32038, Kingdom of Bahrain \\ E-mail: amabdelwakil@uob.edu.bh
}

\author{
Farkhanda Shamim \\ Department of Economics and Finance, College of Business Administration \\ University of Bahrain, P.O. Box 32038, Kingdom of Bahrain \\ E-mail: fshamim@uob.edu.bh
}

Received: May 3, 2015 Accepted: June 14, $2015 \quad$ Published: June 14, 2015

doi:10.5296/ajfa.v7i1.7802 URL: http://dx.doi.org/10.5296/ajfa.v7i1.7802

\begin{abstract}
The objective of this study is to investigate the factors that affect Chief Accounting Officers (CAOs), Chief Financial Officers (CFOs) and other employees' perception of codes of behavior in their organizations in the Kingdom of Bahrain and whether an ethical work environment is influenced by factors such as the establishment of a code of behavior, corporate ethics committee, and/or policy empowerment. The paper is interpretive in nature for which data is collected using survey questionnaires. The findings validate components of an effective code of behavior similar to those identified in the literature which include: implementation of codes of behavior, checking on compliance by internal audit committees, achievement of their goals, follow-up on complaints and confidential channels for reporting ethics violations. Also, results show that the organizations under study generally comply with the values in their codes of behavior. However, the results indicate that the ethical work environment as it currently exists in the Kingdom of Bahrain lacks three aspects. First, setting of a code of behavior seems to be a mixed responsibility between legal departments and outside councils, with minimal participation from the employees. Second, the responsibility to check ethics complaints does not necessarily rest with the ethics committee. Third, lack of a robust mechanism that increases accountants' and financiers' awareness of the importance of COE.
\end{abstract}

Keywords: Accounting Ethics, Code of Ethics, Code of Conduct, Work Environment, Kingdom of Bahrain 


\section{Introduction}

To minimize business and accounting fraud in any organization, there is a need to promote ethical behavior. Ethical deficiency in the accounting profession leads to big disasters in the business world such as Enron, WorldCom and Global Crossing among others. However, it is challenging to balance between private interests and public interests and to avoid accounting fraud (Yen, 2010).

Due to the galloping increase in the number of accounting fraud cases worldwide, corporate codes of behavior - also referred to as corporate codes of ethics or corporate codes of conduct (O'Dwyer and Madden, 2006) - have recently gained legislative momentum and value at both the international and national levels.

At the international level, for example, the Sarbanes-Oxley (SOX) Act of 2002, which became Public Law 107-204 in 2002, is issued with the primary goal of protection of investors by improving the accuracy and reliability of corporate disclosures made pursuant to the securities laws. Section (406) of the SOX Act directed the Securities and Exchange Commission (SEC) to issue rules requiring an issuer of financial reports to disclose whether it had adopted a code of ethics (COE) for its senior financial officers, including its principal financial officer or principal accounting officer. Another example is the 2006 draft issued by the International Federation of Accountants (IFAC) as guidance to help companies develop and implement a code of conduct.

At the national level, the Central Bank of Bahrain (CBB), which is the sole regulator for the financial sector in the Kingdom of Bahrain, requires that an audit committee be formed and preferably there be at least one qualified accountant in the committee. Among the responsibilities of the committee is to review and supervise the operation of the financial institutions' code of conduct. (CBB Rulebook, Volume 1, 2007).

The main differences among the SOX Act, SEC Release and CBB Rulebook related to enhancement of corporate governance are summarized in the Appendix.

For there to be an effective ethical work environment, the implementation of several steps should occur. The COE of the International Federation of Accountants (IFAC), American Institute of Certified Public Accountants (AICPA), Institute of Internal Auditors (IIA), Institute of Management Accountants (IMA) and EDP Auditors Association set the ethical requirements for professional accountants and provide a conceptual framework and concrete guidelines for all professional accountants to ensure conformity with the five fundamental principles of professional ethics. These principles are integrity, objectivity, professional competence, confidentiality, and professional behavior. The first step towards effective ethical work environment is the establishment of a code of conduct, a corporate ethics committee, and a policy empowering the internal audit group to verify compliance with the code as part of its responsibility. The second step is continuous training in dealing with ethical dilemmas. The third and most significant step is a willingness to accept responsibility for one's behavior.

In light of the above, this paper discusses the existence of corporate codes of behavior in the 
workplace in the Kingdom of Bahrain; and if they exist, how are they developed and perceived by the accountants and other employees in the organizations? The paper is interpretative in nature since it attempts to address an issue identified by Muel Kaptein et. al (2008) that for companies a business code is not an instrument that stands in isolation of others and it could even be said that in and of itself it is meaningless: the process of developing and implementing the code is pivotal.

How codes of behavior are received and interpreted may be influenced, to some extent, by the existence of an ethical culture in the business, professionalism and a distinct corporate philosophy. Schlegelmilch and Houston (1989) believe that all three exist in British businesses. The same environment may currently exist in the Kingdom of Bahrain; or if not, may be promoted in businesses in operation.

The specific research questions dealt with in this paper are as follow:

1. Does an ethical work environment exist in the Kingdom's business institutions through the establishment of a code of behavior, corporate ethics committee, and/or policy empowerment within organizations?

2. What are the weaknesses and the potential problem areas in the Kingdom's business institutions' ethics environment?

3. What are the important components of an effective code of behavior for the Kingdom's business institutions?

4. To what extent has there been compliance to the values in codes of behavior in the Kingdom's business institutions?

5. To what extent code of conducts are important for the accounting and financial officers?

The remainder of this paper is organized as follows. Section 2 presents prior international research on ethical codes, followed by Section 3 to describe data and the research methods employed in the study, whereas Section 4 details research findings. Section 5 concludes the study.

\section{Literature Review}

In the last decade of the $20^{\text {th }}$ century, research on business ethics was receiving greater attention (Dunfee and Werhane, 1997). First descriptive study on the ethical behavior of managers was published in 1961 (Baumhart, 1961). The globalization of business and a corresponding increase in ethical conflicts faced by multinational firms such as Nestle, Union Carbide, Enron, WorldCom etc. have spurred research interest in international business ethics.

Many studies attempted to define a corporate code of behaviour such as Pitt and Groskaufmanis (1990) defined it as "any written statement of ethics, law, or policy (or some combination thereof), delineating the obligations of one or more classes of corporate employees". 
Codes of behavior are of two types; namely, Codes of Ethics (COE) and Codes of Conduct (COC). The former (value-based code) outlines principles to guide action while the later (rules-based code) specifies principles to be obeyed (Robin et al., 1989; Farrell and Cobbin, 1996).

In the mid-1970s, the USA was the first major country in the world to experience an extensive movement among large business enterprises in the utilization of COE in their operations. In a study covering several countries such as the US, Canada, Europe, Japan and Australia, Berenbeim (1988) found that companies' COE were less prevalent outside the US and Canada. Beside utilization of COE in business operations it seems that there appears to be a need to understand how the code is 'received' and interpreted by those whose behavior and attitudes it is presumably intended to influence" Cassell et al. (1997).

The first authoritative research produced was from a study by Cressey and Moore (1983) which, among other things, sought to discover corporate executives' views on what it meant to act ethically. Hite et al. (1988) examined the content of 67 ethics codes among Fortune 500 corporations. Their findings indicated frequent misuse of funds and improper accounting, conflicts of interest, political contributions and confidential information. Lefebvre and Singh (1992) observed that it was only recently that specific studies had been undertaken to investigate the content of corporate codes of ethics in North America.

In contrast to the USA research findings, Schlegelmilch and Houston (1989) studied, among other things, the respondents' attitudes towards COE in the UK. They observed that little research had been conducted in the UK on business ethics in general and corporate codes of ethics in particular. This was due to the fact that at that time codes of ethics were not as widely used in the UK. COE was viewed as too general and too broad to be reliable or of any use. Fisher (2001) studied managers' perceptions of ethical codes and concluded that, in various ways, both $\mathrm{COE}$ and $\mathrm{COC}$ contribute to a loss of personal ethical responsibility on the part of employees. In particular, COE undermined or challenged personal integrity, and COC restricted and limited the development of wider loyalties.

Similar studies were conducted in Europe. For example, Langlois and Schegelmilch (1990) surveyed corporate codes in France, Germany and the UK. The codes tended to have "conduct" in their names rather than "ethics". Their findings suggested that there could be difficulties encountered in developing codes for multinational corporations.

In Australia, research into corporate codes has been sparse. Kaye (1992) findings indicated that very few of the firms had COE. Wood (2000) reported that the Australian corporate codes were not distinctly Australian.

In South America, the study by Yuri et.al. (2012) of shape and content of ethic codes in Colombian oil industry indicated that the codes are grouped into three blocks according to their structure: codes of conduct of multinational companies; codes of conduct of local companies with international ambitions; codes of conduct of small local companies. They concluded that codes of global companies are extensive and legalistic. Codes of local companies with international ambitions are short and legalistic while codes of small local 


\section{Macrothink}

Asian Journal of Finance \& Accounting

ISSN 1946-052X

2015, Vol. 7, No. 1

companies are short and missionary. Virtually all codes have their roots in the utilitarian ethics.

Al-Khatib et al. (2001) studied business ethics in three Arab Gulf States; namely, Saudi Arabia, Oman and Kuwait. The findings report that ethical judgments and behaviors are influenced by "an employee's ethical ideology". As such, an employee who is idealistic is expected to exhibit less unethical behavior and vice versa.

To sum up, the literature surveyed so far indicates that there is a substantial presence of corporate codes in many countries such as the US, UK, Canada and Australia. However, more recent research has indicated that there is a gap between the existence of explicit ethical codes and the attitudes and behavior of the organizations (Simon Webley and Andrea Werner 2008; Lawrence 2006; McNulty 2006).

\section{Data and Research Methodology}

Data is collected from a random sample of organizations operating in Bahrain. To minimize sampling bias, organizations are chosen carefully to cover various types of organizations such as those which are listed in the Bahrain Stock Exchange and which are not; local and international organizations; banks and non-banking firms; and small, medium and large sized companies.

A questionnaire is developed incorporating variables identified in the literature as factors that influence the perception of employees towards COB. The questionnaires are distributed by hand and collected from 207 respondents, which constitute the population under study. To minimize any bias in the responses, the questionnaire targets respondents holding different positions in the organization. Table 1 provides background information about the respondents and their organizations.

\subsection{Demographics}

Table 1 summarizes the general characteristics of the respondents. It is observed that most of the respondents $(49.27 \%)$ are from the banking sector, followed by service sector $(21.26 \%)$. This is expected since the Kingdom of Bahrain is known as an international financial market. 
Table 1. Profile of the Sample

\begin{tabular}{|c|c|}
\hline & Frequency (\%) \\
\hline \multicolumn{2}{|l|}{ Sectors } \\
\hline Banking & $102(49.3 \%)$ \\
\hline Investment & $24(11.6 \%)$ \\
\hline Insurance & $15(7.3 \%)$ \\
\hline Service & $44(21.3 \%)$ \\
\hline Industrial & $22(10.6 \%)$ \\
\hline \multicolumn{2}{|l|}{ Location of the firm } \\
\hline Local & $53(25.7 \%)$ \\
\hline International & $153(74.3 \%)$ \\
\hline \multicolumn{2}{|l|}{ Stock Market } \\
\hline Listed in stock market & $96(47.3 \%)$ \\
\hline Not listed in Stock market & $107(52.7 \%)$ \\
\hline \multicolumn{2}{|c|}{ Size of the Organization (measured by \# of employees) } \\
\hline $\mathrm{L}<100$ & $63(36.4 \%)$ \\
\hline $100<\mathrm{L}<500$ & $77(44.5 \%)$ \\
\hline $\mathrm{L}>500$ & $33(19.1 \%)$ \\
\hline \multicolumn{2}{|l|}{ Position } \\
\hline Chief Executive Officer & $16(7.8 \%)$ \\
\hline Chief Financial Officer & $23(11.2 \%)$ \\
\hline Chief Administrative Officer & $11(5.3 \%)$ \\
\hline Chief Accounting Officer & $19(9.2 \%)$ \\
\hline
\end{tabular}

Furthermore, $74.27 \%$ of the respondents are from organizations that have branches outside the Kingdom of Bahrain, while $47.29 \%$ are from organizations listed on the local stock exchange. The fact that the majority of the respondents are from international organizations may have an impact on the results since codes of behavior are more developed and expected to be practiced. Also, $65.70 \%$ of the respondents are from relatively large organizations with more than one hundred employees. Finally, most of the respondents occupied positions other than senior ones. The category "Other" (66.5\%) included human resource employees and auditors.

\section{Results and Discussion}

The respondents are asked to express their opinion on twenty three statements on business ethical behaviors on a five-point scale: 1 (never) to 5 (always). The collected data is analyzed first using descriptive statistics (frequency and percentages). Then analysis of variance is conducted with nature of business as the only factor and the responses to the twenty three statements on COE perspectives as dependent variables to test the null hypotheses that there are no differences in the employees' perception on ethical values in various organization in the Kingdom of Bahrain. 


\subsection{Descriptive Analysis}

A perusal of Table 2 shows that $52.66 \%$ of the respondents believe that their organizations have not adopted a COE, while a majority $(68.60 \%)$ of them has adopted COC. This indicates that organizations operating in the Kingdom of Bahrain are more sensitive to the importance of COC which is rule-based code than COE which is value-based code. Furthermore, these findings concur with the findings of Farrell and Cobbin (2000) in which most of their respondents adopted a rule-based code.

Table 2. Type, Existence and Reasons of Code of Behavior

\begin{tabular}{|c|c|c|}
\hline & No (Percent) & Yes (Percent) \\
\hline \multicolumn{3}{|l|}{ Type of Code of Behavior: } \\
\hline Code of Ethics (COE) & $109(52.66 \%)$ & $98(47.36 \%)$ \\
\hline Code of Conduct (COC) & $65(31.40 \%)$ & $142(68.60 \%)$ \\
\hline None & $201(97.10 \%)$ & $6(2.90 \%)$ \\
\hline \multicolumn{3}{|c|}{ Existence of Code of Behavior for the } \\
\hline Board of Directors & $172(85.57 \%)$ & $29(14.43 \%)$ \\
\hline Chief Executive Officers & $178(88.56 \%)$ & $23(11.44 \%)$ \\
\hline Chief Financial Officer & $172(85.57 \%)$ & $29(14.43 \%)$ \\
\hline Chief Administrative Officers & $183(91.04 \%)$ & $18(8.96 \%)$ \\
\hline Chief Accounting Officer & $176(87.56 \%)$ & $25(12.44 \%)$ \\
\hline All employees & $28(13.93 \%)$ & $173(86.07 \%)$ \\
\hline
\end{tabular}

\section{Reasons for Setting a Code of Behavior}

\begin{tabular}{|l|l|l|}
\hline Prevent misconduct & $77(38.31)$ & $124(61.69)$ \\
\hline Avoid crisis & $93(46.27)$ & $108(53.73)$ \\
\hline Good behavior & $98(49.00)$ & $102(51.00)$ \\
\hline Guide employees & $90(44.78)$ & $111(55.22)$ \\
\hline Protect public & $134(66.67)$ & $67(33.33)$ \\
\hline Protect consumers' and suppliers' interests & $112(55.72)$ & $89(44.28)$ \\
\hline Control conduct & $97(48.26)$ & $104(51.74)$ \\
\hline Others & $188(93.53)$ & $13(6.47)$ \\
\hline
\end{tabular}

It seems that most of the organizations have adopted an overall code of behavior for their employees $(86.07 \%)$; that is, a code of ethics together with a code of conduct. Few respondents indicated that a code of behavior had been adopted for top management such as Board of Directors, Chief Executive Officers, etc. (Table 2). This result may indicate that organizations focus on the existence of $\mathrm{COB}$ for lower level management rather than top management. Furthermore, most of the respondents believe that, to a lesser extent, setting a COB protects the public and it controls behaviors.

Table 3 shows that most of the codes of behavior (42.39\%) had been initiated as late as 2000, indicating the recent awareness of the organizations regarding this matter. The results in Table 


\section{Macrothink}

3 further highlight that a majority of the respondents $(94.5 \%)$ perceive that the code of behavior should be set for all employees so as to prevent misconduct, avoid crisis, encourage good behavior, guide employees and protect consumers and suppliers' interests.

Table 3. Date of Initiating Code of Behavior and Its Need

\begin{tabular}{|c|c|}
\hline & Number of respondents (\%) \\
\hline \multicolumn{2}{|l|}{ Date of Initiating Code of Behavior } \\
\hline $2000-2010$ & $39(42.4 \%)$ \\
\hline 1990-1999 & $20(21.7 \%)$ \\
\hline 1980-1989 & $20(21.7 \%)$ \\
\hline 1970-1979 & $13(14.1 \%)$ \\
\hline \multicolumn{2}{|l|}{ Need for Code of Behavior } \\
\hline Yes For all employees & $189(94.5 \%)$ \\
\hline $\begin{array}{l}\text { Yes for Chief Accounting and Finance } \\
\text { Officers only }\end{array}$ & $7(3.5 \%)$ \\
\hline No need & $4(2 \%)$ \\
\hline
\end{tabular}

\subsubsection{Evaluation of ethical work environment}

Considering the importance of a strong foundation of ethics, the study investigated the existence of the ethics environment in the organizations under study. This was accomplished by studying and analyzing (Tables 4,5 ) factors identified in the literature as components of ethics environment. The strengths and weaknesses of the ethics environment are deduced therein.

Table 4 shows that most of the respondents $(63.45 \%)$ indicated that an ethics committee/officer exists in their organizations and most of these committees $(93.72 \%)$ have at least one financial expert as a member. This result is in line with the recent legislatives at both national and international levels, as outlined at the beginning of this study.

Furthermore, Table 4 reveals one of the weaknesses of the ethics environment under study. The setting of the code of behavior seems to be a mixed responsibility between legal departments and outside councils, with minimal participation from the employees $(15.92 \%)$. This may be a drawback or a cause for potential problem for the organization. It may be better for the organization to establish a code of behavior where the rules are set by the ruled and hence may promote more positive behavior from the employees towards the code of behavior within their organizations. 
Table 4. Components of Ethics Environment

\begin{tabular}{|c|c|c|}
\hline & No & Yes \\
\hline Existence of Ethics Committee/Officer & $72(36.6 \%)$ & $125(63.5 \%)$ \\
\hline Existence of One Financial Expert & $12(6.3 \%)$ & $179(93.7 \%)$ \\
\hline \multicolumn{3}{|l|}{ Setting of Code of Behavior } \\
\hline Legal Department & $117(58.21)$ & $84(41.79)$ \\
\hline Outside Counsel & 143(71.14) & $58(28.86)$ \\
\hline Board of Directors & $135(67.16)$ & $66(32.84)$ \\
\hline Employee Participation & $169(84.08)$ & $32(15.92)$ \\
\hline Chief Executive Officers & $142(70.65)$ & $59(29.35)$ \\
\hline Others & $152(75.62)$ & $49(24.38)$ \\
\hline Global Code of Behavior & $61(30.8 \%)$ & $137(69.2 \%)$ \\
\hline
\end{tabular}

Finally, the fact that the code of behavior is global strengthens the ethics environment $69.19 \%$ since it is available in more than one language.

A further weakness deduced from the results of Table 5 is that the responsibility to check ethics complaints does not lie with the ethics committee $(25.89 \%)$. On a more positive note, most of the respondents $(70.16 \%)$ indicated that the main responsibility for updating the code of behavior lies with the internal parties who may be better acquainted with the ethics environment.

Table 5. Components of Ethics Environment (continued)

\begin{tabular}{|l|l|}
\hline & Number of Respondents (\%) \\
\hline Responsibility to Check on Complaints \\
\hline Ethics Committee & $51(25.9 \%)$ \\
\hline Internal Auditor & $40(20.3 \%)$ \\
\hline Other & $106(53.8 \%)$ \\
\hline Responsibility to Update Code of Behavior \\
\hline External Auditors & $18(9.4 \%)$ \\
\hline Other External Parties & $11(5.8 \%)$ \\
\hline Internal Parties & $134(70.2 \%)$ \\
\hline
\end{tabular}

\subsubsection{Components of an effective code of behavior}

Cassell et al. (1997) stated that "There appears to be a need to understand how the code is 'received' and interpreted by those whose behavior and attitudes it is presumably intended to influence". Whether an employee is receptive to a code of behavior or not depends on the boundaries that employee is ready to accept for any ethic-related code.

In other words, should codes of behavior set by an organization apply to work only or be extended to cover the personal life as well. To understand the boundaries set by the respondents in this study, a question was addressed regarding the monitoring of the employees' behavior during and after office hours. It is revealed that more than 50 percent of the respondents believe that the code of behavior should monitor their behavior during work 
only and not in their personal lives.

Given the boundaries set by the respondents for code of behavior developed by their organizations, Tables 6 and 7 attempted to audit the organization's ethics environment and then identify the important components of an effective code of behavior respectively.

Table 6. Employees' General Perceptions about Codes of Behavior

\begin{tabular}{|l|l|l|l|l|l|}
\hline Variable & Frequently & $\begin{array}{l}\text { When } \\
\text { Needed }\end{array}$ & Sometimes & Rarely & Never \\
\hline Implemented & $123(62.44)$ & $52(26.40)$ & $15(7.61)$ & $3(1.52)$ & $4(2.03)$ \\
\hline Training to deal with dilemmas & $57(28.79)$ & $72(36.36)$ & $35(17.68)$ & $16(8.08)$ & $18(9.09)$ \\
\hline $\begin{array}{l}\text { Internal audit committee checks on } \\
\text { compliance }\end{array}$ & $80(42.11)$ & $65(34.21)$ & $21(11.05)$ & $15(7.89)$ & $9(4.74)$ \\
\hline Updating & $51(26.02)$ & $101(51.53)$ & $19(9.70)$ & $17(8.67)$ & $8(4.08)$ \\
\hline Ethical behavior rewarded & $45(23.44)$ & $17(8.85)$ & $62(32.29)$ & $36(18.75)$ & $32(16.67)$ \\
\hline Accessible to external parties & $33(17.55)$ & $47(25.00)$ & $18(9.57)$ & $23(12.24)$ & $67(35.64)$ \\
\hline $\begin{array}{l}\text { Disclosure policies coordinated with } \\
\text { audit committee }\end{array}$ & $57(31.32)$ & $61(33.52)$ & $43(23.63)$ & $12(6.59)$ & $9(4.94)$ \\
\hline Goals achieved & $85(45.45)$ & $31(16.58)$ & $56(29.95)$ & $10(5.35)$ & $5(2.67)$ \\
\hline Follow up on complaints & $90(46.88)$ & $59(30.73)$ & $20(10.41)$ & $13(6.77)$ & $10(5.21)$ \\
\hline Confidentiality of violations & $96(50.79)$ & $51(26.98)$ & $23(12.17)$ & $13(6.88)$ & $6(3.18)$ \\
\hline Detections of violations & $38(21.23)$ & $32(17.88)$ & $49(27.37)$ & $47(26.26)$ & $13(7.26)$ \\
\hline
\end{tabular}

Clark (2004) proposed performing an audit of a company's ethics environment and suggested some guidelines to do so. Table 6 contains information based on some of Clark's suggestions.

The findings indicate that, of the eleven variables studied, it seems that respondents believe that five of them exist in their organizations' codes of behavior. They include: implementation of codes of behavior, checking on compliance by an internal audit committee, achievement of their goals, follow-up on complaints and confidential channels for reporting ethics' violations.

The key components of an effective code of behavior program that integrates positive values throughout an organization have been identified by Messmer (2003). These components were also investigated in this study. It seems that Messmer's respondents attached high importance to all components (Table 7). This is evident since $74.24 \%$ of the respondents were in agreement that leaders should set the examples for the other employees in the organization by following codes of behavior. The consistent application to all employees was also strongly supported $(70.35 \%)$ in this study. 
Table 7. Importance Attached by Employees to Effective COE Program Components

\begin{tabular}{|l|l|l|l|l|l|}
\hline Variable & $\begin{array}{l}\text { Strongly } \\
\text { Agree }\end{array}$ & Agree & Neutral & Disagree & $\begin{array}{l}\text { Strongly } \\
\text { Disagree }\end{array}$ \\
\hline Leaders set the example & $147(74.24)$ & $32(16.16)$ & $16(8.08)$ & $2(1.01)$ & $1(0.51)$ \\
\hline Ethics as core value & $141(71.57)$ & $45(22.84)$ & $8(4.06)$ & $2(1.02)$ & $1(0.51)$ \\
\hline $\begin{array}{l}\text { All participate in setting } \\
\text { code of behavior }\end{array}$ & $86(43.65)$ & $59(29.95)$ & $27(13.71)$ & $18(9.14)$ & $7(3.55)$ \\
\hline $\begin{array}{l}\text { Application of code of } \\
\text { behavior consistently to all } \\
\text { employees }\end{array}$ & $140(70.35)$ & $40(20.10)$ & $9(4.53)$ & $5(2.51)$ & $5(2.51)$ \\
\hline $\begin{array}{l}\text { Employees feel safe to } \\
\text { share concerns }\end{array}$ & $115(57.79)$ & $62(31.16)$ & $11(5.53)$ & $6(3.01)$ & $5(2.51)$ \\
\hline
\end{tabular}

\subsubsection{Compliance to codes of behavior}

In general, organizations' compliance with codes of behavior including accounting ethics is perceived by respondents to be frequently adhered to integrity, confidentiality, independence, technical Standards, professionalism, public Interest and conflict of interest (Table 8).

Table 8. Employees Perception about Compliance to Codes of Behavior

\begin{tabular}{|l|l|l|l|l|l|}
\hline Values & Frequently & $\begin{array}{l}\text { When } \\
\text { Needed }\end{array}$ & Sometimes & Rarely & Never \\
\hline Integrity & $150(76.14)$ & $28(14.21)$ & $14(7.11)$ & $2(1.02)$ & $3(1.52)$ \\
\hline Confidentiality & $159(80.30)$ & $26(13.13)$ & $8(4.04)$ & $4(2.02)$ & $1(0.51)$ \\
\hline Independence & $142(73.20)$ & $36(18.56)$ & $10(5.15)$ & $5(2.58)$ & $1(0.52)$ \\
\hline Technical Standards & $136(69.74)$ & $38(19.49)$ & $14(7.18)$ & $5(2.56)$ & $2(1.03)$ \\
\hline Professionalism & $148(76.68)$ & $23(11.92)$ & $12(6.22)$ & $6(3.11)$ & $4(2.07)$ \\
\hline Public Interest & $139(71.65)$ & $33(17.01)$ & $13(6.70)$ & $5(2.58)$ & $4(2.06)$ \\
\hline Conflict of Interest & $131(66.84)$ & $35(17.86)$ & $14(7.14)$ & $12(6.12)$ & $4(2.04)$ \\
\hline
\end{tabular}

\subsection{Statistical Analysis}

The data is further analyzed based on the following characteristics of the companies/employees.

- Local versus international ownership

- CAOs and CFOs versus other employees

- Banking versus non-banking sector

- Listed versus non-listed companies

- Small versus medium versus large companies

Comparisons between means are analyzed with analysis of variance which tests the hypothesis that the group means of the dependent variable are equal. 


\subsubsection{Local versus international ownership}

There are 53 firms owned by Bahrainis and 153 internationally owned firms operated in Bahrain.

Table 9. Comparisons of Perceptions by Local versus International Companies

\begin{tabular}{|c|c|c|c|}
\hline \multirow[t]{2}{*}{ Variables } & \multicolumn{2}{|c|}{ Mean Groups } & \multirow{2}{*}{ t-value } \\
\hline & Local & International & \\
\hline Are COE implemented? & 4.54 & 4.43 & 0.81 \\
\hline $\begin{array}{l}\text { Do your employees get training in how to deal with } \\
\text { COE dilemmas? }\end{array}$ & 3.27 & 3.80 & $2.70^{*}$ \\
\hline $\begin{array}{l}\text { Does the internal audit committee check on } \\
\text { compliance with COE? }\end{array}$ & 3.78 & 4.08 & 1.57 \\
\hline How often are the COE updated? & 3.67 & 3.93 & 1.55 \\
\hline Is ethical behavior rewarded? & 2.69 & 3.15 & $2.05 * *$ \\
\hline $\begin{array}{l}\text { Is there access to COE by external parties via } \\
\text { financial reports, Internet etc.? }\end{array}$ & 2.09 & 3.01 & $3.60 *$ \\
\hline $\begin{array}{l}\text { Are all ethics policies related to disclosure } \\
\text { coordinated with the audit committee? }\end{array}$ & 3.48 & 3.90 & $2.21 * *$ \\
\hline $\begin{array}{l}\text { Do you think that the existing COE achieve their } \\
\text { goals? }\end{array}$ & 3.66 & 4.08 & $2.28 * *$ \\
\hline $\begin{array}{l}\text { Is there a follow-up on any filed complaints related to } \\
\text { COE? }\end{array}$ & 3.71 & 4.20 & $2.58^{*}$ \\
\hline $\begin{array}{l}\text { Do confidential channels exist for reporting ethics } \\
\text { violations? }\end{array}$ & 3.72 & 4.29 & $3.18^{*}$ \\
\hline How often are COE violations detected? & 3.13 & 3.22 & 0.42 \\
\hline \multicolumn{4}{|c|}{ In your opinion, does your organization comply with the following values in COE: } \\
\hline Integrity & 4.71 & 4.59 & 0.86 \\
\hline Confidentiality & 4.73 & 4.70 & 0.34 \\
\hline Independence & 4.67 & 4.59 & 0.59 \\
\hline Technical standards & 4.56 & 4.53 & 0.21 \\
\hline Professionalism & 4.60 & 4.57 & 0.15 \\
\hline Public interest & 4.49 & 4.55 & 0.39 \\
\hline Conflict of interest & 4.42 & 4.41 & 0.05 \\
\hline \multicolumn{4}{|l|}{ How do you perceive the importance of the following: } \\
\hline leaders set the example & 4.73 & 4.59 & 1.24 \\
\hline ethics is a core value & 4.80 & 4.58 & $2.03 * *$ \\
\hline everyone participates in setting COE & 4.04 & 4.00 & 0.22 \\
\hline COE is applied consistently to all employees & 4.56 & 4.52 & 0.27 \\
\hline employees feel safe to share concerns & 4.46 & 4.36 & 0.63 \\
\hline
\end{tabular}




\section{Macrothink}

Asian Journal of Finance \& Accounting

ISSN 1946-052X

2015, Vol. 7, No. 1

Table 9 shows that several variables emerged as significantly different at the $0.01,0.05$ and 0.1 levels between local and international organizations.

It appeared that international organizations provided training to their employees in how to deal with COE dilemmas more than their local counterparts $(\mathrm{t}=2.7, \mathrm{p}<0.01)$. This is expected since the international organizations have broader exposure to the issue of ethics in the work environment and hence may well be aware of the importance of training to their employees in this respect. The employees in international organizations who have been trained on how to deal with COE dilemmas may also be aware of the importance of any violations of COE. This is depicted in the variable the employees in the international organizations indicated awareness of the existence of a follow-up procedure on any filed complaints related to $\mathrm{COE}$ $(\mathrm{t}=2.58, \mathrm{p}<0.01)$.

To further understand the previous findings, the study investigated the set-up of the ethics policies and the parties involved in developing them. The results indicated that international organizations may have developed effective COE more than local organizations because they have developed ethics policies that are coordinated with their audit committees $(\mathrm{t}=2.21$, $\mathrm{p}<0.05)$.

Finally, in comparison with international organizations, employees in local organizations perceived ethics as a core value $(\mathrm{t}=2.03, \mathrm{p}<0.05)$. This result may support the argument that codes of behavior may be unnecessary and that an ethical culture, a distinct corporate philosophy and professionalism are deeply valued in the Bahraini business environment that can be promoted without a formal code of ethics.

\subsubsection{CAOs and CFOs versus other employees}

The results of the comparison between accountants' perception towards key components of an effective COE vis-à-vis other employees were generally insignificant. As such, it may be deduced that irrespective of the employee's specialization, all employees carry the same perception towards COE in their respective organizations. However, because of the recent scandals involving the accounting profession and hence the sensitivity of the accountant position in the organization, then organizations in Bahrain may need to develop a more robust mechanism that would increase the awareness of accountants in particular towards the importance of COE. 


\section{Macrothink}

Asian Journal of Finance \& Accounting

ISSN 1946-052X

2015, Vol. 7, No. 1

Table 10. Comparisons of Perceptions by Accountants versus Other employees

\begin{tabular}{|c|c|c|c|}
\hline \multirow[b]{2}{*}{ Variable } & \multicolumn{2}{|c|}{ Mean Groups } & \multirow[b]{2}{*}{ t-value } \\
\hline & Others & $\begin{array}{l}\text { CAOs } \\
\& \\
\text { CFOs }\end{array}$ & \\
\hline Are COE implemented? & 4.78 & 4.41 & $2.01 * *$ \\
\hline Do your employees get training in how to deal with COE dilemmas? & 4.19 & 3.79 & 1.51 \\
\hline Does the internal audit committee check on compliance with COE? & 4.28 & 4.16 & 0.44 \\
\hline How often are the COE updated? & 4.00 & 3.82 & 0.74 \\
\hline Is ethical behavior rewarded? & 3.08 & 3.00 & 0.21 \\
\hline Is there access to COE by external parties via financial reports, Internet etc.? & 2.60 & 2.53 & 0.20 \\
\hline Are all ethics policies related to disclosure coordinated with the audit committee? & 3.92 & 3.59 & 1.23 \\
\hline Do you think that the existing COE achieve their goals? & 4.28 & 3.82 & 1.57 \\
\hline Is there a follow-up on any filed complaints related to COE? & 4.44 & 4.00 & 1.44 \\
\hline Do confidential channels exist for reporting ethics violations? & 4.26 & 3.97 & 1.01 \\
\hline How often are COE violations detected? & 3.30 & 3.00 & 0.91 \\
\hline \multicolumn{4}{|l|}{ In your opinion, does your organization comply with the following values in COE: } \\
\hline Integrity & 4.67 & 4.68 & 0.05 \\
\hline Confidentiality & 4.63 & 4.84 & 1.39 \\
\hline Independence & 4.67 & 4.72 & 0.37 \\
\hline Technical standards & 4.70 & 4.50 & 1.12 \\
\hline Professionalism & 4.63 & 4.61 & 0.08 \\
\hline Public interest & 4.67 & 4.51 & 0.72 \\
\hline Conflict of interest & 4.59 & 4.51 & 0.35 \\
\hline \multicolumn{4}{|l|}{ How do you perceive the importance of the following: } \\
\hline leaders set the example & 4.89 & 4.54 & $2.10 * *$ \\
\hline ethics is a core value & 4.74 & 4.53 & 1.36 \\
\hline everyone participates in setting COE & 4.30 & 3.87 & 1.47 \\
\hline COE is applied consistently to all employees & 4.59 & 4.46 & 0.60 \\
\hline employees feel safe to share concerns & 4.52 & 4.38 & 0.63 \\
\hline
\end{tabular}

* Significant at $0.01 * *$ Significant at $0.05 \quad * * *$ Significant at 0.1 
4.2.3 Banking versus non-banking sector

As reported in Table 1, 50\% of the respondents work in the banking sector which is a dominant industry in Bahrain.

Many variables in Table 11 appear different between banking and non-banking firms at the $1 \%, 5 \%$ and $10 \%$ levels of significance. It is found that as compared to the non-banking sector, the banks in Bahrain act more responsibly in the implementation of code of ethics. They provide training to their employees about COE and internal audit committee keeps an eye on the compliance with COE. The findings are statistically significant at $1 \%$ level. It is also observed that the banks' employees are confident that $\mathrm{COE}$ violations are detected promptly and the existing COE achieve their goals (significant at 5\% and $10 \%$ level respectively).

Interestingly, the respondents are confident that in their banks COE values such as Integrity, Confidentiality, Technical standards, Professionalism, Public interest and Conflict of interest prevail (statistically significant at $1 \%$ and $5 \%$ levels). Furthermore, employees see ethics as core value of COE and they have no reservations in the implementation of COE to all employees and if they have any concern in this regard, they can freely give their opinions. 
Table 11. Comparisons of Perceptions by banking versus Non-banking Sector

\begin{tabular}{|l|l|l|l|}
\hline \multirow{2}{*}{ Variable } & \multicolumn{2}{l|}{ Mean Groups } & \multirow{2}{*}{$\begin{array}{l}\text { Non-bank } \\
\text { ing }\end{array}$} \\
\cline { 2 - 3 } & Banking & \\
\hline Are COE implemented? & 4.65 & 4.25 & $3.3^{*}$ \\
\hline $\begin{array}{l}\text { Do your employees get training in how to deal with COE } \\
\text { dilemmas? }\end{array}$ & 3.92 & 3.42 & $2.95^{*}$ \\
\hline $\begin{array}{l}\text { Does the internal audit committee check on compliance with } \\
\text { COE? }\end{array}$ & 4.29 & 3.68 & $3.85^{*}$ \\
\hline How often are the COE updated? & 3.94 & 3.79 & 1.05 \\
\hline Is ethical behavior rewarded? & 2.95 & 3.13 & 0.91 \\
\hline $\begin{array}{l}\text { Is there access to COE by external parties via financial reports, } \\
\text { Internet etc.? }\end{array}$ & 2.76 & 2.78 & 0.09 \\
\hline $\begin{array}{l}\text { Are all ethics policies related to disclosure coordinated with the } \\
\text { audit committee? }\end{array}$ & 3.86 & 3.72 & 0.87 \\
\hline Do you think that the existing COE achieve their goals? & 4.10 & 3.82 & $1.76^{* * *}$ \\
\hline Is there a follow-up on any filed complaints related to COE? & 4.02 & 4.13 & 0.66 \\
\hline Do confidential channels exist for reporting ethics violations? & 4.09 & 4.21 & 0.75 \\
\hline How often are COE violations detected? & 3.38 & 3.00 & $2.08^{* *}$ \\
\hline
\end{tabular}

In your opinion, does your organization comply with the following values in COE:

\begin{tabular}{|l|l|l|l|}
\hline Integrity & 4.83 & 4.40 & $3.87^{*}$ \\
\hline Confidentiality & 4.84 & 4.56 & $2.99^{*}$ \\
\hline Independence & 4.65 & 4.57 & 0.73 \\
\hline Technical standards & 4.67 & 4.41 & $2.22^{* *}$ \\
\hline Professionalism & 4.74 & 4.41 & $2.57^{* *}$ \\
\hline Public interest & 4.74 & 4.32 & $3.38^{*}$ \\
\hline Conflict of interest & 4.71 & 4.09 & $4.56^{*}$ \\
\hline
\end{tabular}

How do you perceive the importance of the following:

\begin{tabular}{|l|l|l|l|}
\hline leaders set the example & 4.71 & 4.54 & 1.61 \\
\hline ethics is a core value & 4.75 & 4.52 & $2.49^{* *}$ \\
\hline everyone participates in setting COE & 4.06 & 3.96 & 0.63 \\
\hline COE is applied consistently to all employees & 4.74 & 4.31 & $3.45^{*}$ \\
\hline employees feel safe to share concerns & 4.60 & 4.16 & $3.54^{*}$ \\
\hline
\end{tabular}

* Significant at $0.01 * *$ Significant at 0.05 $* * *$ Significant at 0.1

\subsubsection{Listed versus non-listed companies}

There are 96 participating companies which are listed in the stock market, making $52.7 \%$ data 
generated from non-listed companies. Many of the findings are significant (Table 12).

Table 12. Comparisons of Perceptions by listed versus non-listed Companies

\begin{tabular}{|c|c|c|c|}
\hline \multirow{2}{*}{ Variable } & \multicolumn{2}{|c|}{ Mean Groups } & \multirow{2}{*}{ t-value } \\
\hline & Not-listed & Listed & \\
\hline Are COE implemented? & 4.48 & 4.41 & 0.59 \\
\hline $\begin{array}{l}\text { Do your employees get training in how to deal } \\
\text { with COE dilemmas? }\end{array}$ & 3.86 & 3.43 & $2.44 * *$ \\
\hline $\begin{array}{l}\text { Does the internal audit committee check on } \\
\text { compliance with COE? }\end{array}$ & 4.02 & 3.98 & 0.26 \\
\hline How often are the COE updated? & 3.92 & 3.80 & 0.81 \\
\hline Is ethical behavior rewarded? & 3.36 & 2.71 & $3.34^{*}$ \\
\hline $\begin{array}{l}\text { Is there access to COE by external parties via } \\
\text { financial reports, Internet etc.? }\end{array}$ & 2.94 & 2.56 & $1.65^{* * *}$ \\
\hline $\begin{array}{l}\text { Are all ethics policies related to disclosure } \\
\text { coordinated with the audit committee? }\end{array}$ & 3.77 & 3.79 & 0.08 \\
\hline $\begin{array}{l}\text { Do you think that the existing COE achieve their } \\
\text { goals? }\end{array}$ & 4.09 & 3.87 & 1.36 \\
\hline $\begin{array}{l}\text { Is there a follow-up on any filed complaints related } \\
\text { to COE? }\end{array}$ & 4.16 & 3.99 & 1.03 \\
\hline $\begin{array}{l}\text { Do confidential channels exist for reporting ethics } \\
\text { violations? }\end{array}$ & 4.22 & 4.12 & 0.66 \\
\hline How often are COE violations detected? & 3.40 & 2.96 & $2.32 * *$ \\
\hline \multicolumn{4}{|c|}{ In your opinion, does your organization comply with the following values in COE: } \\
\hline Integrity & 4.67 & 4.55 & 1.04 \\
\hline Confidentiality & 4.74 & 4.66 & 0.72 \\
\hline Independence & 4.64 & 4.58 & 0.49 \\
\hline Technical standards & 4.59 & 4.48 & 0.89 \\
\hline Professionalism & 4.62 & 4.52 & 0.71 \\
\hline Public interest & 4.57 & 4.48 & 0.71 \\
\hline Conflict of interest & 4.40 & 4.40 & 0.01 \\
\hline \multicolumn{4}{|l|}{ How do you perceive the importance of the following: } \\
\hline leaders set the example & 4.60 & 4.63 & 0.29 \\
\hline ethics is a core value & 4.70 & 4.56 & 1.48 \\
\hline everyone participates in setting COE & 4.07 & 3.92 & 0.89 \\
\hline COE is applied consistently to all employees & 4.56 & 4.49 & 0.50 \\
\hline employees feel safe to share concerns & 4.42 & 4.34 & 0.59 \\
\hline
\end{tabular}

* Significant at $0.01 * *$ Significant at $0.05 \quad * * *$ Significant at 0.1

Nonetheless, we observe that non-listed companies are more aware of the importance of COE 
and listed companies are aware but to a lesser extent. Non-listed firms reward good behaviors, detect $\mathrm{COE}$ violations and train their employees to deal with $\mathrm{COE}$ dilemma.

\subsubsection{Small, medium and large companies}

In our analysis, we divide companies with respect to their number of employees. Large firms employ more than 500 skilled and unskilled workers, medium size firms have between 100 and 500 employees while the small firms are hiring around 100 employees. The number of respondents from various types of firms are reported in Table 1. When compared, their means are significantly different from each other for various variables. We observe that small and medium sized firms are applying COE more than the larger firms (Table 13). This observation is in line with the findings that listed companies are not significantly implementing, training or detecting COE in their organizations. (Table 12). 
Table 13. Comparisons of Perceptions by Small, Medium and Large Companies

\begin{tabular}{|c|c|c|c|c|}
\hline \multirow{2}{*}{ Variable } & \multicolumn{3}{|c|}{ Mean Groups } & \multirow{2}{*}{ t-value } \\
\hline & $\mathbf{L}<\mathbf{1 0 0}$ & $\mathbf{1 0 0}>\mathrm{L}<\mathbf{5 0 0}$ & $\mathbf{L}>\mathbf{5 0 0}$ & \\
\hline Are COE implemented? & 4.71 & 4.43 & 4.09 & $2.35^{*}$ \\
\hline $\begin{array}{l}\text { Do your employees get training in how to deal with COE } \\
\text { dilemmas? }\end{array}$ & 3.83 & 3.88 & 3.00 & $2.63 *$ \\
\hline $\begin{array}{l}\text { Does the internal audit committee check on compliance } \\
\text { with COE? }\end{array}$ & 4.19 & 3.94 & 3.58 & $1.76^{* *}$ \\
\hline How often are the COE updated? & 3.93 & 3.97 & 3.31 & $2.30 * *$ \\
\hline Is ethical behavior rewarded? & 2.91 & 3.17 & 2.82 & 0.98 \\
\hline $\begin{array}{l}\text { Is there access to COE by external parties via financial } \\
\text { reports, Internet etc.? }\end{array}$ & 2.71 & 2.93 & 2.55 & 0.82 \\
\hline $\begin{array}{l}\text { Are all ethics policies related to disclosure coordinated } \\
\text { with the audit committee? }\end{array}$ & 3.88 & 4.00 & 3.17 & $2.49 *$ \\
\hline Do you think that the existing COE achieve their goals? & 3.85 & 4.23 & 3.47 & $2.32 *$ \\
\hline $\begin{array}{l}\text { Is there a follow-up on any filed complaints related to } \\
\text { COE? }\end{array}$ & 3.81 & 4.26 & 4.32 & $1.88^{* *}$ \\
\hline $\begin{array}{l}\text { Do confidential channels exist for reporting ethics } \\
\text { violations? }\end{array}$ & 3.78 & 4.42 & 4.19 & $2.34 *$ \\
\hline How often are COE violations detected? & 3.17 & 3.30 & 3.03 & 0.68 \\
\hline
\end{tabular}

In your opinion, does your organization comply with the following values in COE:

\begin{tabular}{|l|l|l|l|l|}
\hline Integrity & 4.81 & 4.58 & 4.50 & 1.46 \\
\hline Confidentiality & 4.75 & 4.65 & 4.82 & 0.83 \\
\hline Independence & 4.61 & 4.59 & 4.64 & 0.22 \\
\hline Technical standards & 4.57 & 4.65 & 4.27 & $1.52^{* * *}$ \\
\hline Professionalism & 4.74 & 4.61 & 4.24 & $1.81^{* *}$ \\
\hline Public interest & 4.62 & 4.59 & 4.39 & 0.87 \\
\hline Conflict of interest & 4.53 & 4.48 & 4.12 & 1.39 \\
\hline
\end{tabular}

How do you perceive the importance of the following:

\begin{tabular}{|l|l|l|l|l|}
\hline leaders set the example & 4.66 & 4.58 & 4.79 & 0.98 \\
\hline ethics is a core value & 4.84 & 4.63 & 4.61 & $1.57^{* * *}$ \\
\hline everyone participates in setting COE & 3.88 & 4.07 & 4.30 & 1.25 \\
\hline COE is applied consistently to all employees & 4.68 & 4.66 & 4.12 & $2.30^{* *}$ \\
\hline employees feel safe to share concerns & 4.44 & 4.45 & 4.06 & $1.53^{* * *}$ \\
\hline
\end{tabular}

* Significant at $0.01 * *$ Significant at 0.05 *** Significant at 0.1

\section{Summary and Conclusions}

The main objective of this study is to investigate the perceptions of employees related to 
codes of behavior and accounting ethics in the Kingdom of Bahrain. In particular, the study focused on four main issues. First, an examination was conducted as to whether an ethical work environment exists through the establishment of: a code of behavior, corporate ethics committee, and policy empowerment. The existence of an ethical work environment was validated by the results of the study. Three main weaknesses in the ethics environment of some organizations were identified: (1) setting of the code of behavior seems to be a mixed responsibility between legal departments and outside councils, with minimal participation from the employees, (2) the responsibility to check ethics complaints does not lie with the ethics committee and (3) lack of a robust mechanism that enhances financiers' and accountants' awareness about the importance of accounting ethics. Additionally, some important components of an effective code of behavior were identified such as implementation of codes of behavior, checking on compliance by an internal audit committee, achievement of their goals, follow-up on complaints and confidential channels for reporting ethics violations. Finally, results revealed that the organizations under study generally comply with the values in their codes of behavior.

Overall, the results indicate that international organizations operating in Bahrain, banks and relatively smaller firms may to a great extent, be in line with what has been identified as factors essential for the existence of an effective ethical work environment.

It is pointed out that the use of questionnaires may limit the generalization ability of the results and replication of the study or use of different methodologies may enhance the results.

This study may set the foundation for further research in this area in the Kingdom of Bahrain. In particular, a follow-up may be conducted to investigate the sustainability of COE in an ever-changing financial environment and whether more rigorous COE should be developed to enhance the importance of its existence within the organization. Additionally, factors identified by other researches such as the degree of idealism in employees (Al Khatib et. al 2002) should also be considered.

\section{References}

Al-Khatib, J.A., Robertson C.J., Stanton A. \& Vitell S.J. (2001). Business Ethics in Arab Gulf States: A Three Country Study. International Business Review, 11(1), 97-111. http://dx.doi.org/10.1016/S0969-5931(01)

Baumhart, R.C. (1961). How Ethical Are Businessmen? Harvard Business Review, 39, 6-176.

Berenbeim, R. (1988). Ethics codes and educational programs (part2). Security Management, 32(10), 91-7.

Cassell, C., Johnson, P. \& Smith, K. (1997). Opening the Black Box: Corporate Codes of Ethics in their Organisational Context. Journal of Business Ethics, 16, 1077-1093. http://dx.doi.org/10.1023/A:1017926106560

Central Bank of Bahrain (CBB) circular EDBS/.../2004: High Level Controls Requirements for Banks - Enhancing Corporate Governance. 
Central Bank of Bahrain (CBB). Disclosure Standards. December 2003.

Central Bank of Bahrain, Rulebook Volume 1, HC 1, 3.12 Conventional banks, 2007.

Clark, S. (2004). Ethics Audit Essential for Every Business. The Business Journal of Milwaukee.

Cravath, Swaine \& Moore. (2003). Codes of Ethics and Financial Experts- Disclosure Pursuant to Sections 406 and 407 of Sarbanes-Oxley. Retrieved from http://www.cravath.com/memo/2224182_6.pdf

Cressy, D. \& Moore, C. (1983). Managerial values and corporate codes of ethics. California Management Review, 25(4), 53-77. http://dx.doi.org/10.2307/41165032

Dunfee, T.W. \& Werhane, P. (1997). Report on business ethics in north America. Journal of Business Ethics, 16(14), 1589-1595. http://dx.doi.org/10.1023/A:1005871200181

Farrell, B.J. \& Cobbin, D.M. (1996). A content analysis of codes of ethics in Australian enterprises. Journal of Managerial Psychology, 11(1), 37-55. http://dx.doi.org/10.1108/02683949610109381

Farrell, B.J. \& Cobbin, D.M. (2000). A content analysis of codes of ethics from fifty-seven national accounting organizations. Journal of Business Ethics, 9(3). http://dx.doi.org/10.1111/1467-8608.00189

Fisher, C. (2001). Managers' perceptions of ethical codes: dialectics and dynamics. Journal of Business Ethics, 10(2), 145-156. http://dx.doi.org/10.1111/1467-8608.00225

Gorbaneff, Y., Margarita, E., Uribe, G. \& Hoyos, G. (2012). Forma y contenido de los códigos de ética de empresas petroleras en Colombia. Shape and content of ethic codes in Colombian oil industry. Investigación y Desarrollo. jul-dic, 20(2), 366-389.

Harvard Law Review Notes. (2003). The Good, the Bad, and their Corporate Codes of Ethics: Enron, Sarbanes-Oxley, and the Problems with Legislating Good Behavior. Harvard Law Review, 116(7), 2123-2141. http://dx.doi.org/10.2307/1342755

Hite, R., Bellizzi, J., \& Fraser, C. (1988). A content analysis of ethical policy statements regarding marketing activities. Journal of Business Ethics, 7(10), 771-6. http://dx.doi.org/10.1007/BF00411024

International Federation of Accountants. (1997). IFAC handbook. New York: International Federation of Accountants.

International Federation of Accountants. (2007). Internal auditor update, New York: International Federation of Accountants.

Kaptein, M. \& Schwartz, M.S. (2008). The Effectiveness of Business Codes: A Critical Examination of Existing Studies and the Development of an Integrated Research Model. Journal of Business Ethics. http://dx.doi.org/10.1007/s10551-006-9305-0

Kaye, B. (1992). Codes of ethics in Australian business corporations. Journal of Business 
Ethics, 11(11), 857-62. http://dx.doi.org/10.1007/BF00872364

Langlois, C. \& Schegelmilch, B. (1990). Do corporate codes of ethics reflect national character: evidence from Europe and the United States? Journal of International Business Studies, 21(4), 519-39. http://dx.doi.org/10.1057/palgrave.jibs.8490340

Lawrence, F. (2006). Salmonella outbreaks kept secret by Cadbury in 2003. The Guardian, 5 July.

Lefebvre, M. \& Singh, J. (1992). The content and focus of Canadian corporate codes of ethics. Journal of Business Ethics, 11(10), 799-808. http://dx.doi.org/10.1007/BF00872312

McNulty, S. (2006). BP employees issued early warning of Prudhoe corrosion. Financial Times, 9 August.

Messmer, M. (2003). Does Your Company Have a Code of Ethics. Strategic Finance, April.

O'Dwyer, B. \& Madden, G. (2006). Ethical Codes of Conduct in Irish Companies: A Survey of Code Content and Enforcement Procedures. Journal of Business Ethics, 63(3), 217-236. http://dx.doi.org/10.1007/s10551-005-3967-x

Pitt, H.L. \& Groskaufmanis, K.A. (1990). Minimizing Corporate Civil and Criminal Liability: A Second Look at Corporate Codes of Conduct. The Georgetown Law Journal, 78.

Robin, D., Giallourakis, M., David, F.R. \& Moritz, T.E. (1989). A different look at codes of ethics. Business Horizons, 32(1), 66-73. http://dx.doi.org/10.1016/0007-6813(89)90028-1

Sarbanes-Oxley Act, (2002). Sarbanes-Oxley Public Company Accounting Reform and Investor Protection Act. Retrieved from http//www.sarbanes-oxley.com.

Schlegelmilch, B.B. \& Houston, J.E. (1989). Corporate codes of ethics in large UK companies: an empirical investigation of use, content and attitudes. European Journal of Marketing, 23(6), 7-24. http://dx.doi.org/10.1108/EUM0000000000571

SEC Release No. 34-46701 dated October 22, 2002 (the Proposing Release), which sets for the original proposals by the SEC for the rules to be promulgated under Sections 406 of Sarbanes-Oxley.

Webley S. \& Werner, A. (2008). Corporate codes of ethics: necessary but not sufficient. $\begin{array}{lllll}\text { Business } \quad \text { Ethics: } & \text { European }\end{array}$ http://dx.doi.org/10.1111/j.1467-8608.2008.00543.x

Wood, G. (2000). A cross cultural comparison of the contents of codes of ethics: USA, Canada and Australia. Journal of Business Ethics, 25(4), 287-98. http://dx.doi.org/10.1023/A:1006034209956

Yen, V.H. (2010). Accounting Ethics And Its Important Role For Reduction Of Accounting Fraud: An Empirical Study In Hanoi. BS Thesis, HELP University College, Hanoi. Retrieved from http://dl.is.vnu.edu.vn/bitstream/123456789/223/1/Vu\%20Hai\%20Yen.pdf 
APPENDIX

\section{Comparative Analysis of Information Related to Code of Behaviour}

The main differences between the SOX Act, SEC Release and CBB circular related to enhancement of corporate governance are summarized below.

\begin{tabular}{|c|c|c|c|}
\hline REQUIREMENT & $\begin{array}{l}\text { SOX ACT } \\
\text { (SECTION } \\
406)\end{array}$ & SEC & CBB \\
\hline $\begin{array}{l}\text { Adopt Code of } \\
\text { Behaviour for?? }\end{array}$ & $\begin{array}{l}\text { Principal } \\
\text { financial } \\
\text { officer or } \\
\text { principal } \\
\text { accounting } \\
\text { officer }\end{array}$ & $\begin{array}{l}\text { Principal executive } \\
\text { officers and senior } \\
\text { financial officers }\end{array}$ & $\begin{array}{l}\text { Board of Directors, senior } \\
\text { management and employees }\end{array}$ \\
\hline Implementation date & $30^{\text {th }}$ July 2002 & $\begin{array}{l}\text { Fiscal year ending on or } \\
\text { after } 15^{\text {th }} \text { July } 2003\end{array}$ & $1^{\text {st }}$ January 2005 \\
\hline Suggested content & $\begin{array}{l}\text { Not addressed } \\
\text { in Section } \\
(406) \text {. }\end{array}$ & $\begin{array}{l}\text { Details are not } \\
\text { specified. The decision } \\
\text { as to specific provisions } \\
\text { of each issuer's COE } \\
\text { should be made by the } \\
\text { issuer itself. }\end{array}$ & $\begin{array}{l}\text { - Commitment to the code } \\
\text { - Commitment to the law } \\
\text { and best practice } \\
\text { standards. } \\
\text { - Employment practices } \\
\text { e.g. health and safety } \\
\text { - How the company deals } \\
\text { with disputes and } \\
\text { complaints from clients } \\
\text { and polices the code } \\
\text { - Confidentiality }\end{array}$ \\
\hline Disclosure & $\begin{array}{l}\text { Not addressed } \\
\text { in Section } \\
(406) \text {. }\end{array}$ & $\begin{array}{l}\text { Annual Report, Form } \\
8 \text {-K or on its Internet } \\
\text { website. }\end{array}$ & $\begin{array}{l}\text { Communicated throughout the } \\
\text { organization. }\end{array}$ \\
\hline Audit Committee & $\begin{array}{l}\text { Not addressed } \\
\text { in Section } \\
(406) \text {. }\end{array}$ & $\begin{array}{l}\text { - At least one } \\
\text { audit } \\
\text { committee } \\
\text { financial } \\
\text { expert. } \\
\text { - The name of } \\
\text { the expert must } \\
\text { be disclosed. }\end{array}$ & $\begin{array}{l}\text { - Preferably, there should } \\
\text { be at least one qualified } \\
\text { accountant in the } \\
\text { committee. } \\
\text { - Among committee's } \\
\text { responsibilities is to } \\
\text { review and supervise the } \\
\text { operation of the COE. }\end{array}$ \\
\hline
\end{tabular}

